\title{
Vascular Plant Diversity in Burned and Unburned Alvar Woodland: More Evidence of the Importance of Disturbance to Biodiversity and Conservation
}

\author{
Paul CATling
}

Agriculture and Agri-Food Canada, Environmental Health, Biodiversity, Wm. Saunders Building, Central Experimental Farm, Ottawa, Ontario K1A 0C6 Canada; e-mail: catlingp@agr.gc.ca

Catling, Paul M. 2009. Vascular plant biodiversity in burned and unburned alvar woodland: more evidence of the importance of disturbance to biodiversity and conservation. Canadian Field-Naturalist 123(3): 240-245.

Vascular plant biodiversity was compared in an unburned semi-open alvar woodland dominated by conifers and an equivalent woodland that had burned nine years previously and had developed into a long-lasting successional shrubland. The comparison, based on 30 quadrats $1 \mathrm{~m}^{2}$ at each of two sites, revealed less than $25 \%$ similarity in the vegetation cover of the two sites. The successional alvar shrubland that developed following fire had twice as many species and more regionally rare species than the corresponding woodland site. The shrubland also had higher values for various biodiversity measures that take heterogeneity and evenness into account. These data provide additional evidence for the importance of fire and disturbance in the creation of successional habitat upon which biodiversity depends. A cautious use of fire in management of alvars is supported.

Key Words: vascular plant, alvar, biodiversity, rare species, disturbance, fire, succession, Simpson's Index, Shannon-Wiener function, Brillouin's Index, Smith and Wilson evenness, Ontario.

A number of articles have featured the beneficial effect of fire on rarer vascular plants and overall plant biodiversity on the Burnt Lands Alvar (Brunton 1986*; Catling and Brownell 1999; Catling et al. 2001, 2002; Catling and Sinclair 2002) and have suggested that the removal of biomass on a large scale may contribute significantly to the protection of biodiversity on alvars (e.g., Catling et al. 2001, 2002). These articles were based on studies within a year after a fire and 37 years after a fire. Here diversity of vascular plants is compared in two sites: (1) a semi-open woodland dominated by conifers and (2) successional shrubland resulting from a fire nine years previously that had replaced woodland corresponding to, and nearly adjacent to, the woodland at site 1 . The description of these two habitats has additional importance since they have been utilized in comparisons (published elsewhere) of insect biodiversity based on sampling with pitfall traps and nets.

\section{Methods and Materials}

\section{The study area}

The woodland study site in West Carleton, City of Ottawa, ca. $4.6 \mathrm{~km}$ east-northeast of Almonte (Lanark County), Ontario, included 4 ha (approximately 10 acres) centred on $45.2569^{\circ} \mathrm{N},-76.1437^{\circ} \mathrm{W}$. The corresponding burned woodland study site $0.5 \mathrm{~km}$ to the southeast also included 4 ha, centred on $45.2507^{\circ} \mathrm{N}$, $-76.1337^{\circ} \mathrm{W}$. Based on personal observation prior to the fire, examination of pre-fire aerial photographs, and determination of identity of burned trees, both of these study areas had been semi-open, mixed forest dominated by conifers until 23 June 1999, when a fire swept through 152 ha, including the southern study site. Both sites appeared to be similar in their vegetation throughout prior to the fire and both were of similar and unchanging elevation. At the time of the study, both sites were surrounded by similar vegetation for $100 \mathrm{~m}$ on all sides, the burned site by burned woodland and the unburned site by unburned woodland. At both sites, prior to the fire, the semi-open woodland was dominated by (in order of importance) Thuja occidentalis, Picea glauca, Populus tremuloides, Abies balsamea, and Pinus strobus, with an understory of mosses, including Hylocomium splendens and Dicranum polysetum, and occasional depauperate shrubs, including Juniperus communis. This is believed to be climax vegetation for these sites, since some trees are killed by drought leading to recolonization of the early successional tree species. The area has long been known to be particularly subject to fire, and it was named the Burnt Lands by settlers in 1870, at the time of the second most recent fire. For more information on this area, see White (1979), Brunton (1986*), and Catling et al. (2001, 2002).

\section{Description of the vegetation}

In August 2008, 30 quadrats $1 \mathrm{~m}^{2}$ were placed approx. $3 \mathrm{~m}$ apart along a transect through the centre of each site. One was placed directly over each of ten pitfall insect traps (at each site) and the other two were placed $2 \mathrm{~m}$ away. Thus there were 30 quadrats of $1 \mathrm{~m}^{2}$ in each of the burned woodland and the unburned woodland. For each quadrat the percentage cover (represented by half of the surface area) of all plants to $1 \mathrm{~m}$ tall was estimated for each species of vascular plant, for bryophytes as a group, and for lichens as a group. The two sites were compared with regard to 

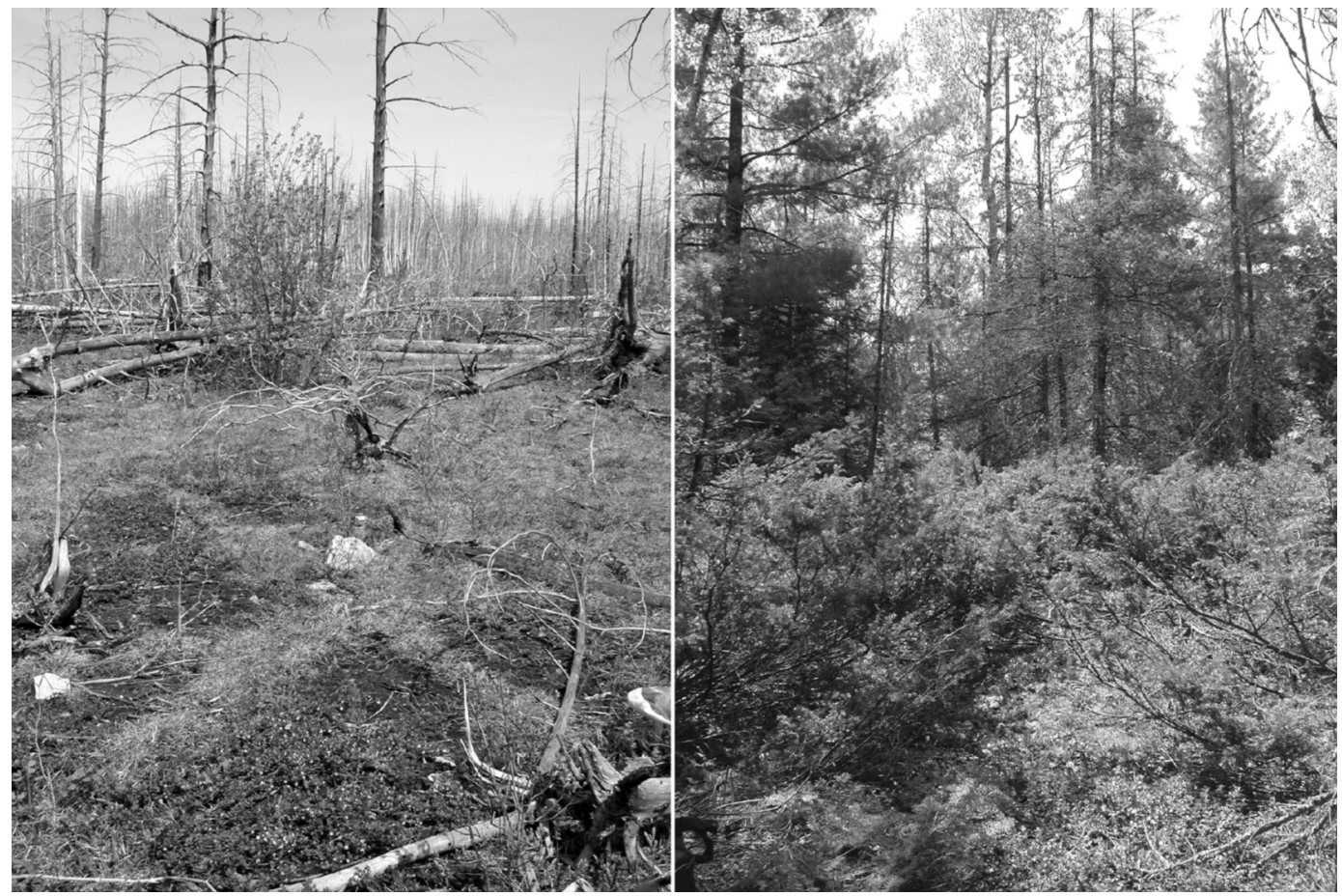

FIGURE 1. Burned (left) and unburned (right) alvar woodland on the Burnt Lands Alvar in western Ottawa. On the left, fallen and dead standing trees are Abies balsamea, Picea glauca, Pinus strobus, and Thuja occidentalis. Regrowth on upper left is Populus tremuloides, and Arctostaphylos uva-ursi can be seen flowering in the foreground. In the righthand photograph, the forest is dominated by Abies balsamea, Picea glauca, Pinus banksiana, Pinus strobus, Populus tremuloides, and Thuja occidentalis. Shrubs of Juniperus communis are present in the foreground. The photo on the left showing the area burned on 23 June 1999 was taken at $45.2507^{\circ} \mathrm{N},-76.1437^{\circ} \mathrm{W}$. The photo on the right was taken at $45.2569^{\circ} \mathrm{N},-76.1437^{\circ} \mathrm{W}$. (Photos: P. M. Catling, late May 2008)

the dominant species (frequency and cover) and biodiversity and to the value to pollinating insects. The plants were identified using Fernald (1950) and the online Flora of North America series (Flora of North America 1993-2009), and the names mostly follow the recent compilation of Kartesz and Meacham (1999). Vouchers of vascular plants are preserved in the National Collection of Agriculture and Agri-Food Canada in Ottawa (DAO), and vouchers of lichens and mosses are in the collection of the Canadian Museum of Nature (CAN).

\section{Comparison and biodiversity measures}

Sites were compared to determine the extent of distinctness, since sites that are more distinct would have higher biodiversity value. This aspect was evaluated with regard to the number of species in common and the percentage of the total cover provided by those common species (at both sites) compared to the combined cover of all species at both sites.

The two sites were also compared with respect to the presence of rare and restricted species. Regional rarity was determined by reference to the list of regionally rare species developed by Brunton $\left(2005^{*}\right)$.
The measures of biodiversity employed here for comparison were (1) total number of species and the frequency and cover of each species; (2) the reciprocal of Simpson's Index based on probability which weights common and dominant species; (3) the exponential form of the Shannon-Wiener function that is based on information theory and weights rare species more heavily; (4) Brillouin's Index, which employs numbers of individuals or, in this case, instances (i.e., frequency), and assumes no replacement; and (5) the Smith and Wilson evenness measure, which is sensitive to both rare and common species and is independent of species richness. These widely employed measures are all described by Krebs (1999); associated software was used for the computations (Krebs $2008 *$ ).

\section{Results}

The unburned site was a semi-open forest with dominant trees being (in order of importance) Thuja occidentalis, Picea glauca, Populus tremuloides, Abies balsamea, and Pinus strobus. The understory was dominated by Carex eburnea and bryophytes, mostly Hylo- 
TABLE 1. Plant species with average cover and frequency values for plants less than $1 \mathrm{~m}$ tall in unburned semi-open alvar woodland. The tree cover was dominated by (in order of importance) Thuja occidentalis, Picea glauca, Populus tremuloides, Abies balsamea, and Pinus strobus, The species are arranged in descending order of average percentage cover value, then by frequency, then alphabetically. The data are based on 30 quadrats $1 \mathrm{~m}^{2}$ at least $2 \mathrm{~m}$ apart sampling an area of 4 ha. Species marked with two asterisks (**) are regionally and/or provincially rare. Species marked with + are introduced.

\begin{tabular}{|c|c|c|}
\hline Species & $\begin{array}{l}\text { Average } \% \\
\text { Cover }\end{array}$ & Frequency \\
\hline Bryophytes (mostly Pleurozium schreberi and Dicranum polysetum & 42.50 & 27 \\
\hline Carex eburnea Boott, Bristle-leaf Sedge & 40.26 & 23 \\
\hline Carex richardsonii $\mathrm{R}$. Br., Richardson's Sedge ** & 8.10 & 21 \\
\hline Symphoricarpos albus (L.) Blake, Common Snowberry & 6.00 & 19 \\
\hline Arctostaphylos uva-ursi (L.) Spreng., Red Bearberry & 4.53 & 13 \\
\hline Juniperus communis L. var. depressa Pursh, Common Juniper & 3.70 & 5 \\
\hline Waldsteinia fragarioides (Michx.) Tratt. ssp. fragarioides, Appalachian Barren-Strawberry & 2.03 & 10 \\
\hline Prunella vulgaris L., Common Selfheal & 1.96 & 6 \\
\hline Oryzopsis asperifolia Michx., White-grain Mountain-Rice Grass & 1.60 & 17 \\
\hline Symphyotrichum (Aster) ciliolatum (Lindl.) A. \& D. Löve, Lindley's American-Aster & 1.30 & 6 \\
\hline Abies balsamea (L.) P. Mill., Balsam Fir & 1.06 & 6 \\
\hline lichens (unidentified) & 1.00 & 3 \\
\hline Thuja occidentalis L., Eastern Arborvitae & 0.90 & 6 \\
\hline Maianthemum canadense Desf., False Lily-of-the-Valley & 0.66 & 6 \\
\hline Rosa acicularis Lindl. ssp. sayi (Schwein.) W. H. Lewis, Prickly Rose & 0.63 & 8 \\
\hline Aquilegia canadensis L., Red Columbine & 0.60 & 8 \\
\hline Fragaria viginiana Duchesne ssp. virginiana, Virginia Strawberry & 0.46 & 7 \\
\hline Picea glauca (Moench) Voss, White Spruce & 0.43 & 4 \\
\hline Danthonia spicata (L.) Beauv. ex Roemer \& J. A. Schultes, Poverty Wild Oat Grass & 0.33 & 6 \\
\hline Shepherdia canadensis (L.) Nutt., Russet Buffalo-Berry & 0.26 & 3 \\
\hline Rhamnus cathartica L., European Buckthorn + & 0.20 & 3 \\
\hline Frangula alnus P. Mill., Glossy False Buckthorn + & 0.20 & 4 \\
\hline Toxicodendron (Rhus) rydbergii, (Small ex Rydb.) Greene, Western Poison Ivy & 0.16 & 3 \\
\hline Cypripedium parviflorum Salisb. var. pubescens (Willd.) Knight, Lesser Yellow Lady's-Slipper & 0.16 & 4 \\
\hline Solidago juncea Ait., Early Goldenrod & 0.13 & 3 \\
\hline Hieracium piloselloides Vill., Tall Hawkweed + & 0.13 & 2 \\
\hline Achillea millefolium L. var. millefolium, Common Yarrow & 0.13 & 2 \\
\hline Linaria vulgaris P. Mill., Greater Toadflax + & 0.10 & 3 \\
\hline Hypericum perforatum L., Common St. John's-Wort + & 0.10 & 2 \\
\hline Clinopodium vulgare L., Wild Basil & 0.10 & 2 \\
\hline Chimaphila umbellata (L.) W. Bart. ssp. cisatlantica (Blake) Hultén, Pipsissewa & 0.10 & 4 \\
\hline Amelanchier alnifolia (Nutt.) Nutt. ex M. Roemer var. compacta (Nielsen) McKay, Saskatoon ** & 0.10 & 3 \\
\hline Viola nephrophylla Greene, Northern Bog Violet & 0.06 & 3 \\
\hline Packera (Senecio) paupercula (Michx.) A. \& D. Löve, Balsam Groundsel & 0.06 & 2 \\
\hline Epipactis helleborine (L.) Crantz, Helleborine + & 0.06 & 2 \\
\hline Solidago nemoralis Ait. var. nemoralis, Gray Goldenrod & 0.03 & 2 \\
\hline Populus tremuloides Michx., Quaking Aspen & 0.03 & 2 \\
\hline Lonicera tatarica L., Common Honeysuckle + & 0.03 & 2 \\
\hline Antennaria sp. (cf. neglecta), Pussytoes & 0.03 & 2 \\
\hline Total & 120.22 & \\
\hline
\end{tabular}

${ }^{1}$ Mostly Pleurozium schreberi and Dicranum polysetum

comium splendens and Dicranum polysetum (Table 1). There was no obvious change in the vegetation following the fire in the adjacent area. Thirty-seven vascular plants were recorded in the understory, 30 of which were native. Only Carex eburnea and bryophytes were prominent. The total cover averaged $120.22 \mathrm{~m}^{2}$ per quadrat. The seven introduced species represented $0.66 \%$ of the total cover.

All vegetation in the burned site, including trees, had been killed by the fire. Nine years after the fire, the burned area had developed into a long-lasting succes- sional shrubland dominated by shrubs, such as Prunus virginiana, Arctostaphylos uva-ursi, Amelanchier alnifolia var. compacta, and Symphoricarpos albus, and herbs, such as Danthonia spicata and Carex richardsonii (Table 2). Seventy-four vascular plants were recorded in the burned site, 11 of which were introduced, leaving 63 native. The total cover averaged $167.59 \mathrm{~m}^{2}$ per quadrat. The introduced species accounted for $4.56 \%$ of the total cover.

The successional habitat that developed following a fire in boreal semi-open alvar woodland is thought 
TABLE 2. Average cover and frequency values for plants less than $1 \mathrm{~m}$ tall in treeless burned alvar woodland 10 years after the fire. Tree cover was previously dominated by Abies balsamea, Picea glauca, Pinus strobus, Populus tremuloides, and Thuja occidentalis. The species are arranged in descending order of average percentage cover value, then by frequency, then alphabetically. The data are based on 30 quadrats $1 \mathrm{~m}^{2}$ at least $2 \mathrm{~m}$ apart within an area of 4 ha. Species marked with two asterisks $(* *)$ are regionally and/or provincially rare. Species marked with + are introduced. Species marked + ? are possibly introduced.

\begin{tabular}{|c|c|c|}
\hline Species & $\begin{array}{c}\text { Average } \% \\
\text { cover }\end{array}$ & Frequency \\
\hline Danthonia spicata (L.) Beauv. ex Roemer \& J. A. Schultes, Poverty Wild Oat Grass & 28.26 & 32 \\
\hline Prunus virginiana L., Choke Cherry & 22.43 & 14 \\
\hline Arctostaphylos uva-ursi (L.) Spreng., Red Bearberry & 18.13 & 19 \\
\hline Amelanchier alnifolia (Nutt.) Nutt. ex M. Roemer var. compacta (Nielsen) McKay, Saskatoon ** & 14.43 & 11 \\
\hline Carex richardsonii $\mathrm{R}$. Br., Richardson's Sedge ** & 13.83 & 31 \\
\hline Symphoricarpos albus (L.) Blake, Common Snowberry & 7.76 & 18 \\
\hline Rosa acicularis Lindl. ssp. sayi (Schwein.) W. H. Lewis, Prickly Rose & 5.00 & 15 \\
\hline Populus tremuloides Michx., Quaking Aspen & 5.00 & 6 \\
\hline Toxicidendron (Rhus) rydbergii (Small ex Rydb.) Greene, Western Poison Ivy & 4.13 & 16 \\
\hline Cornus sericea (stolonifera) L. ssp. sericea, Redosier & 3.63 & 8 \\
\hline Solidago nemoralis Ait. var. nemoralis, Gray Goldenrod & 3.46 & 16 \\
\hline Symphyotrichum (Aster) ciliolatum (Lindl.) A. \& D. Löve, Lindley’s American-Aster & 3.03 & 17 \\
\hline Oligoneuron album (S. asteroides, ptarmicoides) (Nutt.) Nesom, Prairie Flat-Top-Goldenrod & 2.90 & 7 \\
\hline Packera (Senecio) paupercula (Michx.) A. \& D. Löve, Balsam Groundsel & 2.70 & 17 \\
\hline Fragaria virginiana Duchesne ssp. virginiana, Virginia Strawberry & 2.43 & 15 \\
\hline Hypericum perforatum L., Common St. John's-Wort + & 1.96 & 11 \\
\hline Carex eburnea Boott, Bristle-leaf Sedge & 1.86 & 11 \\
\hline Poa compressa L., Flat-Stem Blue Grass + & 1.86 & 6 \\
\hline Bryum sp., bryophyte & 1.80 & 8 \\
\hline Muhlenbergia glomerata (Willd.) Trin., Spiked Muhly & 1.73 & 9 \\
\hline Pinus banksiana Lamb., Jack Pine & 1.66 & 3 \\
\hline Solidago juncea Ait., Early Goldenrod & 1.36 & 12 \\
\hline Hieracium piloselloides Vill., Tall Hawkweed + & 1.06 & 14 \\
\hline Campanula rotundifolia $\mathrm{L} .$, Bluebell & 1.00 & 11 \\
\hline Astragalus neglectus (Torr. \& Gray) Sheldon, Cooper's Milk-Vetch ** & 1.00 & 3 \\
\hline Carex umbellata Schkuhr ex Willd., Parasol Sedge & 0.96 & 10 \\
\hline Echium vulgare L., Common Viper's-Bugloss + & 0.96 & 5 \\
\hline Viola adunca Sm. var. adunca, Hook-Spur Violet ** & 0.76 & 8 \\
\hline Penstemon hirsutus (L.) Willd., Hairy Beardtongue & 0.76 & 7 \\
\hline \multicolumn{3}{|l|}{ Dichanthelium acuminatum (Sw.) Gould \& C. A. Clark var. fasciculatum (Torr.) } \\
\hline Freckman, Tapered Rosette Grass & 0.73 & 4 \\
\hline Aquilegia canadensis L., Red Columbine & 0.63 & 6 \\
\hline Juniperus communis L. var. depressa Pursh, Common Juniper & 0.60 & 5 \\
\hline Trifolium hybridum L., Alsike Clover + & 0.56 & 8 \\
\hline Medicago lupulina L., Black Medick + & 0.53 & 11 \\
\hline Rubus idaeus L. ssp. strigosus (Michx.) Focke, Common Red Raspberry & 0.53 & 6 \\
\hline Anemone cylindrica Gray, Long-Head Thimbleweed & 0.50 & 7 \\
\hline Apocynum cannabinum L., Indian-Hemp & 0.50 & 3 \\
\hline Calystegia spithamea (L.) Pursh ssp. spithamea, Low False Bindweed ** & 0.46 & 7 \\
\hline Polygala senega L., Seneca-Snakeroot & 0.43 & 5 \\
\hline Solidago canadensis L. var. canadensis, Canadian Goldenrod & 0.40 & 4 \\
\hline Lilium philadelphicum L. var. philadelphicum, Wood Lily & 0.40 & 4 \\
\hline Taraxacum officinale G. H. Weber ex Wiggers ssp. officinale, Common Dandelion + & 0.33 & 6 \\
\hline Cypripedium parviflorum Salisb. var. pubescens (Willd.) Knight, Lesser Yellow Lady's-Slipper & 0.33 & 5 \\
\hline Sisyrinchium montanum Greene var. crebrum Fern., Strict Blue-Eyed-Grass & 0.33 & 3 \\
\hline Waldsteinia fragarioides (Michx.) Tratt. ssp. fragarioides, Appalachian Barren-Strawberry & 0.26 & 4 \\
\hline Euthamia graminifolia (L.) Greene var. graminifolia, Flat-top Goldenrod & 0.26 & 4 \\
\hline Bromus kalmii (Gray) Holub, Kalm’s Brome ** & 0.26 & 4 \\
\hline Panicum flexile (Gattinger) Scribn., Wiry Panic Grass ** & 0.26 & 3 \\
\hline Erigeron philadelphicus L. var. philadelphicus, Philadelphia Fleabane & 0.26 & 3 \\
\hline Elymus trachycaulus (Link) Gould ex Shinners ssp. trachycaulus, Slender Wild Rye & 0.26 & 3 \\
\hline Rosa blanda Ait., Smooth Rose & 0.23 & 5 \\
\hline Isanthus brachiatus (L.) B.S.P. (Trichostema brachiatum), False Pennyroyal & 0.23 & 4 \\
\hline Tragopogon dubius Scop., Meadow Goat's-Beard + & 0.23 & 3 \\
\hline Scutellaria parvula Michx. var. parvula, Small Skullcap & 0.20 & 5 \\
\hline Sporobolus vaginiflorus (Torr. ex Gray) Wood var. vaginiflorus, Poverty Dropseed & 0.20 & 4 \\
\hline
\end{tabular}


TABLE 2. (continued)

\begin{tabular}{|c|c|c|}
\hline Species & $\begin{array}{c}\text { Average } \% \\
\text { cover }\end{array}$ & Frequency \\
\hline Rhus aromatica Ait. var. aromatica, Fragrant Sumac & 0.20 & 4 \\
\hline Rubus odoratus L. var. odoratus, Purple-Flowering Raspberry & 0.20 & 3 \\
\hline Viola nephrophylla Greene, Northern Bog Violet & 0.16 & 4 \\
\hline Rhus typhina L., Stag-Horn Sumac & 0.13 & 4 \\
\hline Pteridium aquilinum (L.) Kuhn var. latiusculum (Desv.) Underwood ex Heller, Bracken Fern & 0.13 & 4 \\
\hline Prunella vulgaris L. ssp. vulgaris, Common Selfheal & 0.13 & 3 \\
\hline Diervilla lonicera P. Mill., Northern Bush-Honeysuckle & 0.13 & 3 \\
\hline Potentilla norvegica L. ssp. monspeliensis (L.) Aschers. \& Graebn., Norwegian Cinquefoil +? & 0.13 & 1 \\
\hline Dichanthelium linearifolium (Scribn. \& Nash) Gould, Slim-Leaf Rosette Grass & 0.10 & 3 \\
\hline Arenaria serpyllifolia L., Thyme-Leaf Sandwort + & 0.10 & 3 \\
\hline Eurybia (Aster) macrophylla (L.) Cass., Large-Leaf Wood-Aster & 0.06 & 4 \\
\hline Arabis hirsuta (L.) Scop. var. pycnocarpa (M. Hopkins) Rollins, Hairy Rockcress ** & 0.06 & 4 \\
\hline Veronica peregrina L. ssp. xalapensis (Kunth) Pennell, Neckweed & 0.06 & 3 \\
\hline Verbascum thapsus L., Great Mullein + & 0.03 & 3 \\
\hline Silene antirrhina L., Sleepy Catchfly & 0.03 & 3 \\
\hline Hedeoma hispida Pursh, Rough False Pennyroyal & 0.03 & 3 \\
\hline Geranium bicknellii Britt., Northern Crane's-Bill & 0.03 & 3 \\
\hline Clinopodium vulgare L., Wild Basil & 0.03 & 3 \\
\hline Cirsium discolor (Muhl. ex Willd.) Spreng., Field Thistle ** & 0.03 & 3 \\
\hline Cirsium vulgare (Savi) Ten., Bull Thistle + & 0.03 & 3 \\
\hline Agrostis hyemalis (Walt.) B.S.P., Winter Bent & 0.03 & 3 \\
\hline Total & 167.59 & \\
\hline
\end{tabular}

to be relatively long-lasting, since trees were observed to be invading slowly nine years after the fire and their establishment would only be possible following successful competition with a well-established shrubland flora. In the woodland, young trees represented $2.01 \%$ of the total cover, but in the burned woodland, after nine years, young trees represented only $3.97 \%$.

The two sites had only $16.33 \%$ of species in common, and these common species accounted for only $24.77 \%$ of the combined cover of both sites. Consequently, the vegetation was $>75 \%$ different with respect to biomass. There were nine regionally rare species in the burned area with a cover value of $31.09 \%$. Only two regionally rare species, with a cover value of $2.85 \%$ were present in the unburned woodland.

Not only were there almost twice as many species in the burned site as well as higher frequency and cover values, but the values for all biodiversity indices and an evenness measure were also higher for the burned area (Table 3). Introduced species contributed to overall biodiversity, but they were a minor component at both sites, resulting in only slightly higher values than for native species alone.

\section{Discussion}

The development of successional plant communities on alvar landscapes is likely to promote vascular plant biodiversity, which is often highest in mid-successional stages. The post-fire succession on alvars is unique and has high vascular plant biodiversity, so including fire, or an alternative biomass removal method, in the management plan for portions of an alvar landscape is appropriate, if not essential. With the decline of ecological processes such as natural fire, it is to be anticipated that certain kinds of successional communities will be lost. Without dedicated management of protected areas, there will be declines in biodiversity. However, taking into account the extent to which fires occurred on alvars (Jones and Reschke 2005), the occurrence of unique species in alvar woodlands (personal observation), and the susceptibility of some species to fire (Siemann et al. 1996), only portions of alvar landscapes should be burned at any particular time.

Important considerations for fire management include the following: (1) maximum successional changes occur in early stages (Catling et al. 1999, 2001, 2002); (2) succession proceeds at different rates in different places; (3) the pre-settlement fire return interval on Great Lakes alvar landscapes was at least 200-500 years (Jones and Reschke 2005); and (4) there may be little change in many alvar woodlands more than 100 years old due to the maintenance by drought of early successional forest dominated by conifers. These considerations suggest that an alvar landscape with maximum biodiversity would include alvar woodlands burned 10, 30, 60, 100, and 200 years previously. After 100 years of management, the first burned area may have returned to alvar woodland. Of course, there are many considerations, such as maintaining sufficiently large wooded areas for forest-nesting birds, and adjustments to speed up the burn cycle may be necessary during the management period. Although the management 
TABLE 3. Biodiversity measures for all species/native species in burned and unburned alvar woodland.

\begin{tabular}{lcc}
\hline \hline & \multicolumn{2}{c}{ Alvar woodland } \\
\cline { 2 - 3 } Biodiversity measure & Burned & Unburned \\
\hline Number of species & $76 / 65$ & $39 / 32$ \\
Total cover & $167.59 / 159.94$ & $120.22 / 119.4$ \\
Total frequency & $553 / 540$ & $254 / 236$ \\
Simpson Index reciprocal (cover) & $12.51 / 11.44$ & $4.04 / 3.98$ \\
Simpson Index reciprocal (frequency) & $45.39 / 37.76$ & $20.09 / 17.61$ \\
Shannon-Wiener function (cover) & $4.43 / 4.23$ & $2.77 / 2.71$ \\
Shannon-Wiener function (frequency) & $5.87 / 5.62$ & $4.77 / 4.52$ \\
Brillouin's Index (frequency) & $5.52 / 5.28$ & $4.41 / 4.20$ \\
Smith-Wilson evenness (cover) & $0.21 / 0.20$ & $0.18 / 0.17$ \\
Smith-Wilson evenness (frequency) & $0.73 / 0.72$ & $0.66 / 0.65$ \\
\hline \hline
\end{tabular}

of alvars with fire is complex, failure to attempt it is failure to simulate a natural process that preserves biodiversity.

Future studies of biodiversity and its relation to succession on alvar landscapes are needed to determine the extent to which diversity of various animal groups corresponds to that for vascular plants. This would also help to improve the general understanding of the effectiveness of easily surveyed plants in predicting biodiversity of animals which has a number of constraints (Wolters et al. 2006).

\section{Acknowledgments}

The Ontario Ministry of Natural Resources provided information on Burnt Lands Provincial Park, where the study was undertaken. D. F. Brunton provided extensive information on the biological resources of the Burnt Lands.

Documents Cited (marked $*$ in text)

Brunton, D. F. 1986. A life science inventory of the Burnt Lands. Ministry of Natural Resources. 118 pages +3 maps.

Brunton, D. F. 2005. Vascular plants of the City of Ottawa, with identification of significant species. Appendix A of Urban Natural Areas Environmental Evaluation Study, Final Report. By Muncaster Environmental Planning and Brunton Consulting Services for Planning and Growth Management Department, City of Ottawa, Ottawa.

Krebs, C. 2008. Ecological Methodology, programs for ecological methodology. $2^{\text {nd }}$ edition. Exeter Software, Setauket, New York.

\section{Literature Cited}

Catling, P. M., and V. R. Brownell. 1999. Importance of fire in alvar ecosystems-evidence from the Burnt Lands, eastern Ontario. Canadian Field-Naturalist 112: 661-667.

Catling, P. M., and A. Sinclair. 2002. Initial beneficial effects of fire and bulldozing on Neglected Milkvetch, Astragalus neglectus, in an eastern Ontario alvar woodland. Canadian Field-Naturalist 116: 640-642.

Catling, P. M., A. Sinclair, and D. Cuddy. 2001. Vascular plants of a successional alvar burn 100 days after a severe fire and their mechanisms of re-establishment. Canadian Field-Naturalist 115: 214-222.

Catling, P. M., A. Sinclair, and D. Cuddy. 2002. Plant community composition and relationships of disturbed and undisturbed alvar woodland. Canadian Field-Naturalist 116: 571-579.

Fernald, M. L. 1950. Gray's manual of botany. American Book Company, Boston. 1632 pages.

Flora of North America Editorial Committee. 1993-2009. Flora of North America. http://www.efloras.org/flora_page. aspx?flora_id=1.

Jones, J., and C. Reschke. 2005. The role of fire in Great Lakes alvar landscapes. Michigan Botanist 44: 13-27.

Kartesz, J. T., and C. A. Meacham. 1999. Synthesis of the North American Flora, Version 1.0. North Carolina Botanical Garden, Chapel Hill, North Carolina.

Krebs, C. 1999. Ecological methodology. $2^{\text {nd }}$ edition. Addison Wesley Longman Inc., New York. 620 pages.

Siemann, E., J. Haarstad, and D. Tilman. 1996. Short term and long term effects of burning on Oak savanna arthropods. American Midland Naturalist 137: 349-361.

White, D. J. 1979. Burnt Lands Alvar. Trail and Landscape 13: $34-38$

Wolters, V., J. Bengtsson, and A. Zaitsev. 2006. Relationship among the species richness of different taxa. Ecology 87: 1886-1895.

Received 10 June 2009

Accepted 7 April 2010 